\title{
ИНСТИТУТ ПУБЛИЧНЫХ УСЛУГ В РОССИИ: ПЕРСПЕКТИВЫ В КОНТЕКСТЕ ЕВРОПЕЙСКОГО ОПЫТА
}

И нститут публичных услуг за последние годы прочно укрепился в действующем российском законодательстве и, по нашему убеждению, должен занять положенное ему центральное место в отрасли и науке административного права, принимая во внимание как зарубежный опыт, так и направления проводимой в России административной реформы. Именно эта тенденция способна преодолеть сохраняющийся в доктрине и практике стереотип, в соответствии с которым административное право ассоциируется с вертикальными отношениями в области государственного управления, основанными на властном подчинении одной стороны другой. Нельзя не замечать глубинные преобразования, которые переживает система публичного администрирования: контрольные и юрисдикционные функции исполнительных органов отходят на второй план, основная же задача публичной администрации состоит в том, чтобы эффективно и гарантированно обеспечивать удовлетворение потребностей частных лиц в публично-правовой сфере.

В свете отмеченных обстоятельств представляется чрезвычайно важным избрать методологически верный подход к определению категории публичных услуг, их видов, а следовательно, и направлений развития соответствующего правового института. Очевидно, что в этих вопросах необходимо ориентироваться не только на текущие политические установки и отечественные правовые традиции, но и опыт других стран, в частности государств Европы, где, собственно, зародился и длительное время эволюционирует соответствующий институт. Между тем публичные услуги «по-российски» отнюдь не тождественны традиционному их пониманию за рубежом.

1. Опыт ЕС: от национальных концепций к общеевропейской доктрине служб общего значения

Для обозначения рассматриваемого феномена в государствах континентальной Европы используются различные категории, отражающие разные теоретические подходы.

1.1. Во Франции сложилась концепция nубличных служб (service public), развитие и научное обоснование которой связываются, прежде всего, с именем Л. Дюги, который видел в государстве систему социально полезных служб ${ }^{1}$. Впоследствии в литературе и судебной практике было признано, что обязанности отдельных публичных служб (в особенности тех, которые имеют экономическую природу) могут возлагаться также на субъекты частного права ${ }^{2}$. Подобный подход охватил не только традиционные властные прерогативы государства, но и сферы, в которых отношения способны строиться по модели гражданско-правовых обязательств. В итоге категория публичных служб стала системообразующей для административного права Франции и трактуется весьма широко - как любая обязательная деятельность во всеобщих интересах, осуществляемая под руководством субъекта публичного права ${ }^{3}$.

Ж.-М. Понтье пишет, что публичная служба традиционно определяется посредством двух составляющих ее аспектов: организационного и материального; первый связан с лицами, осуществляющими публич-

1 Schweitzer H. Services of General Economic Interest: European Law's Impact on the Role of Markets and Member States // Market Integration and Public Services in the European Union / Ed. by M. Cremona. New York: Oxford University Press, 2011. P. 13-14.

2 Dreyfus M. France // The Changing Legal Framework for Services of General Interest in Europe. Between Competition and Solidarity / Ed. by M. Krajewski, U. Neergaard, J. van de Gronden. The Hague: T.M.C. Asser press. 2009. P. 270-272.

3 См.: Gaudemet Y. Traité de droit administratif. T. 1. Droit administratif general. 16e éd. P.: LGDJ, 2001. P. 737-776; Dupuis G., Guédon M.-J., Chrétien P. Droit administratif. 9e éd. P.: Dalloz, 2004. P. 508-552; Rivero J., Waline J. Droit administrative. 19e éd. P.: Dalloz, 2002. P. 449-464. 
ную службу (субъекты публичного права, а также уполномоченные субъекты частного права), второй с содержанием деятельности, главную цель которой представляет общественная польза. При этом автор отмечает, что понятие общественной пользы как необходимое условие для функционирования публичной службы относительно; в такой стране, как Франция, оно постоянно меняется в зависимости от времени, а также от представлений политических руководителей, которые и определяют, при некотором контроле со стороны судов, что представляет собой общественная польза; еще больше ситуацию осложняет тот факт, что общественная польза неодинаково трактуется в разных государствах, что определяется особенностями их истории и культуры ${ }^{4}$ В целом, как справедливо указывает Э.В. Талапина, публичные службы во французской доктрине - это родовое понятие, объединяющее все виды общезначимой и обязательной деятельности публичных лиц как на национальном, так и на локальном уровнях, в том числе материальная деятельность (юстиция, почта, телефон, вода, газ, электричество, уборка мусора, детские сады), финансовая деятельность (субвенции, кредиты, социальная помощь, пособия, стипендии), культурная деятельность (публичное образование) и др. ${ }^{5}$

Таким образом, категорию французских публичных служб было бы некорректно обозначать термином «публичные услуги», поскольку, во-первых, феномен служб охватывает как саму деятельность, так и субъекта ее осуществления в их единстве и, во-вторых, функционирование служб не всегда носит характер предоставления в пользу частных лиц. Например, доступ к отдельным службам и их имуществу может в принципе запрещаться для граждан под угрозой уголовного наказания (вооружение, казармы).

Важное значение для институализации публичных служб имело то обстоятельство, что с начала XX в. во французской доктрине стало общепринятым распространение на имущество, предназначенное для нужд публичной службы, правового режима объектов публичной собственности (domaine public) ${ }^{6}$. В настоящее время, если быть точным, речь идет об имуществе, которое принадлежит субъекту публичного права и спе-

4 См.: Понтье Ж.-М. Предоставление публичных услуг частными лицами // Административные процедуры и контроль в свете европейского опыта / под ред. Т.Я. Хабриевой, Ж. Марку. М., 2011 / СПС «КонсультантПлюс». Абз. 2060-2072.

5 См.: Талапина Э.В. Административное право Франции сегодня // Ежегодник сравнительного правоведения. - М., 2004. - C. 136-151.

6 См.: Auby J.-M., Bon P., Auby J.-B. Droit administratif des biens. 4e éd. P.: Dalloz, 2003. - P. 38-39. циально приспособлено для осуществления функций публичной службы ${ }^{7}$.

Французская концепция публичных служб, в том числе правового режима принадлежащего им имущества, с учетом определенных трансформаций и национальной специфики, была принята во многих государствах континентальной правовой семьи (Испания ${ }^{8}$, Италия ${ }^{9}$, страны Латинской Америки ${ }^{10}$ и др.).

Однако в ряде стран обязательная публично значимая деятельность получила несколько иную трактовку. Прежде всего речь идет о Германии, где в качестве базовой используется категория «государственное управление», которое разграничивается на два вида: негативное вмешательство и ограничения (Eingriffsverwaltung) и позитивное - предоставление публичных услуг (Leistungsverwaltung) $^{11}$. Таким образом, к примеру, обеспечение общественной безопасности и порядка с позиций права ФРГ, в отличие от французского, не охватывается публичными услугами. Немецкая доктрина публичных услуг, формирование которой связано главным образом с именем Э. Форстхоффа, опирается на введенное им понятие «обеспечение жизнедеятельности» (Daseinsvorsorge) $^{12}$. Ответственным за жизнеобеспечение выступает государство, которое может использовать как публично-правовые, так и частноправовые формы предоставления публичных услуг; при этом в последние десятилетия государство все дальше уходит от монопольного производства и предоставления публичных услуг, оставаясь лишь гарантом и делегируя соответствующие функции субъектам частного права ${ }^{13}$.

В соответствии с немецкой доктриной, в отличие о французской, имущество, используемое для предо-

См.: ст. L2111-1 Общего кодекса собственности лиц публичного права (Code général de la propriété des personnes publiques) Франции 2006 г. // http://www.legifrance.gouv.fr.

8 См., напр.: Sánchez Morón M. Derecho administrativo: Parte general. $7^{\mathrm{a}}$ ed. - Madrid: Tecnos, 2011. - P. 763-789.

9 См., напр.: Corradino M. Il diritto amministrativo. II edizione. - Padova: CEDAM, 2009. - P. 1273-1162.

10 См., напр.: El Derecho Administrativo Iberoamericano (Estudios y Comentarios, № 9) / Dir. S. González-Varas Ibáñez, Coord. F. Villalba Pérez. Granada (España): Instituto Nacional de Administración Pública, Unión Iberoamericana de Municipalistas, 2005. P. 79-86, 127-129, 171-173, 260-267, 312-320, 341-349, 386388, 425-428, 476-480, 529-531, 627-636, 729-733, 781-785.

11 См.: Васильева А.Ф. Административно-правовое регулирование публичных услуг в Германии и России: сравнительно-правовой анализ: дис. ... канд. юрид. наук. - СПб., 2009. - C. 6-7.

12 Forsthoff E. Rechtsfragen der leistenden Verwaltung. Stuttgart: Kohlhammer. 1959.

13 Васильева А.Ф. Указ. соч. - С. 18-20 и др. 
ставления публичных услуг, не образует особой «публичной собственности», однако во многих случаях оно может быть причислено к категории так называемых публичных вещей (öffentlichen Sachen) - объектов собственности, которые принадлежат различным лицам, но всегда обременены использованием в интересах общего блага, в данном случае предназначены для предоставления публичных услуг ${ }^{14}$.

Таким образом, Франция и Германия предложили альтернативные доктрины обязательной публично значимой деятельности государства (service public и Daseinsvorsorge), которые до настоящего времени трактуются в качестве конкурирующих ${ }^{15}$.

1.2. В 90-х годах минувшего столетия в условиях формирования общеевропейского рынка сфера публичных служб (жизнеобеспечения) становится более открытой, в нее приникают конкурентные начала ${ }^{16}$. $\mathrm{B}$ результате в рамках европейской интеграции рассмотренные концепции подверглись адаптации, а соответствующие базовые понятия стали исчезать из актов Европейского Союза (далее - ЕС). На сегодня в документах ЕС вместо выражения «публичные службы» (англ.: public services) все больше используется термин «службы общего значения» (англ.: services of general interest, SGIs), которые упоминаются в ст. 14, 106 Договора о функционировании ЕС и отдельном Протоколе № 26 о службах общего значения (в редакции Лиссабонского договора 2007 г.) $)^{17}$. Вместе с тем в европейской литературе эти термины зачастую продолжают употребляться как синонимы, однако уже в том смысле, который в них вкладывают документы ЕС.

Формулировки базовых актов ЕС, в том числе после подписания Лиссабонского договора, закрепляют понятие служб общего значения лишь в общих чертах, в связи с чем особою роль в интерпретации этой категории приобретают многочисленные документы Еврокомиссии, отражающие процесс преобразований

\footnotetext{
14 Как известно, несмотря на усилия О. Майера, концепция публичной собственности (öffentlichen Eigentum) была отвергнута в странах германского права. На сегодняшний день в законодательстве, судебной практике и юридической науке ФРГ господствует доктрина «модифицированной частной собственности» (modifizierten Privateigentum) на публичные вещи (см, например: Papier H.-J. Recht der öffentlichen Sachen. 3. Aufl. Berlin: De Gruyter, 1998. S. 5-11).

15 Schweitzer H. Op. cit. - P. 15-16.

16 Cremona M. Introduction // Market Integration and Public Services in the European Union. P. 2.

17 См., напр.: Европейский Союз: Основополагающие акты в редакции Лиссабонского договора с комментариями / отв. ред. С.Ю. Кашкин, пер. А.О. Четвериков. - М., 2007 / СПС «КонсультантПлюс».
}

в рассматриваемой сфере. Так, в 2007 г. Еврокомиссия пришла к выводу, что указанный термин объединяет экономические и неэкономические службы, которые публичные власти квалифицируют в качестве имеющих общее значение и возлагают на них соответствующие специфические обязательства; это означает, что именно публичные власти соответствующего уровня принимают решения по поводу природы и охвата службы общего значения; при этом публичные власти вправе предоставлять соответствующие услуги самостоятельно либо доверить их оказание другим лицам, как частным, так и публичным, действующим на коммерческой или некоммерческой основе ${ }^{18}$. Однако независимо от того кому принадлежит или под чьим управлением находится SGIs, соответствующая деятельность подчиняется интенсивному регулированию в публичных интересах. Сколько-нибудь подробная регламентация правового режима имущественной основы служб общего значения отсутствует и вряд ли возможна, поскольку ст. 345 Договора о функционировании ЕС закрепляет, что заключенные договоры ни в чем не наносят ущерба существующим в государствах-членах системам прав собственности.

Службы общего значения подразделяются в ЕС на две разновидности: службы общеэкономического значения и неэкономические службы общего значения. Четкое их разграничение не произведено; критерием для дифференциации выступает не сфера услуг, не статус субъекта и не способ финансирования, а скорее природа деятельности и условия, в которых функционирует служба, т. е. применяется функциональных подход ${ }^{19}$.

Службы общеэкономического значения (англ.: services of general economic interest, SGEI) ${ }^{20}$ включают транспортные, почтовые, телекоммуникационные службы, службы электроснабжения, газоснабжения, водоснабжения, общественного телерадиовещания, обращения с отходами и другие службы, необходимые для нормального функционирования экономики в целом, для благосостояния всех членов общества. Государства - члены ЕС компетентны предоставлять данные услуги, поручать и финансировать их оказание при соблюдении принципов и условий функционирования

\footnotetext{
18 Commission Communication «Services of general interest, including social services of general interest: a new European commitment», COM (2007) 725 final // http://eur-lex.europa.eu.

19 Cremona M. Op. cit. - P. 3.

20 Используется в праве ЕС и близкий к SGEI, однако более узкий по содержанию термин «универсальные службы» (англ.: universal services) (Micklitz H.-W. Universal Services: Nucleus for Social European Private Law // Market Integration and Public Services in the European Union. - P. 63-102).
} 
служб общеэкономического значения, установленных Европейским Парламентом и Советом ${ }^{21}$. Служба считается экономической, если соответствующие услуги предоставляются по общему правилу за вознаграждение, при этом необязательно, чтобы именно получатель услуги производил оплату. Следовательно, одно и то же предприятие может предоставлять как экономические, так и неэкономические услуги, и такое разграничение предельно важно с точки зрения действия правил $\mathrm{EC}^{22}$.

Неэкономические службы общего значения (англ.: non-economic services of general interest), по мнению Еврокомиссии, охватывают, прежде всего, «традиционные прерогативы государств», в частности полицию, правосудие и установленные законом виды социального обеспечения; при этом акты ЕС не ограничивают компетенцию государств-членов предоставлять неэкономические услуги общего значения, поручать или организовывать их оказание с учетам соблюдения общего принципа недискриминации ${ }^{23}$. Таким образом, в той части, в которой публичные службы (услуги), не затрагивают экономической деятельности, вопросов конкуренции и функционирования общего рынка, они регламентируются на национальном уровне.

В рамках служб общего значения отдельно в документах ЕС выделяются так называемые соииальные службы общего значения (англ.: social services of general interest, SSGI), им посвящены специальные исследования ${ }^{24}$. По мнению Еврокомиссии, такие службы могут быть как экономическими, так и неэкономическими по своей природе в зависимости от конкретных направлений деятельности. Несмотря на

21 SGEI подчинены, в частности, правилам, относящимся к функционированию общего рынка, публичным закупкам, защите прав потребителей, конкуренции, предоставлению государственной поддержки. При этом в отношении отдельных SGEI, таких как телекоммуникационные и почтовые службы, службы газо- и электроснабжения, телерадиовещания (частично), применяются специальные режимы, установленные в рамках ЕC (Neergaard U. Services of General Economic Interest: The Nature or the Beast / The Changing Legal Framework for Services of General Interest in Europe. Between Competition and Solidarity. - P. 17-50).

22 В частности, по делу Парижского аэропорта Европейский Суд пришел к выводу, что одно и тоже лицо может быть вовлечено, с одной стороны, в административную деятельность, которая не является экономической (например, выполнение задач полиции), а с другой - в сугубо коммерческую деятельность (Case C-82/01 Aéroports de Paris [2002] // http://eur-lex.europa.eu).

23 $\operatorname{COM}(2007) 725$ final.

24 См., напр.: Social Services of General Interest in the EU / Ed. U.U. Neergaard, E. Szyszczak, J.W. van de Gronden, M. Krajewski. Springer, 2013. отсутствие официального закрепления, считается, что социальные службы подразделяются на два вида: во-первых, установленное законом и дополнительное социальное страхование, организованное различными способами и охватывающее основные жизненные риски, связанные с состоянием здоровья, старостью, несчастными случаями, безработицей, выходом на пенсию и инвалидностью, и, во-вторых, службы социальной поддержки в трудных ситуациях, занятости и профессиональной подготовки, социального жилья и долгосрочного ухода, а также другие службы, функционирующие непосредственно в пользу граждан. Анализируемые службы организованы, как правило, на местном уровне и в значительной степени зависимы от публичного (бюджетного) финансирования ${ }^{25}$.

2. Российский опыт: проблемы модернизации правового регулирования

В отечественной науке и законодательстве не сформировано целостной и общепринятой концепции публичных услуг. В частности, сохраняются различные их трактовки с точки зрения субъектов их предоставления, содержания, источников финансирования и соотношения со смежными направлениями публично значимой деятельности ${ }^{26}$. Законодатель и вовсе избегает термина «публичные услуги», оперируя понятиями «государственные услуги» и «муниципальные услуги».

Категория государственных и мунициипальных услуг на законодательном уровне впервые была закреплена в 1998 г. в Бюджетном Кодексе Российской Федерации (далее - БК РФ) в ключе обеспечения минимальных социальных стандартов. Впоследствии положения бюджетного законодательства в анализируемой части испытали немало корректив с сохранением базовой концепции. Действующая редакция Кодекса в ст. 6 предусматривает, что государственные и муниципальные услуги - это услуги, оказываемые государ-

25 См. подробнее: Communication from the Commission «Implementing the Community Lisbon programme: Social services of general interest in the European Union», COM (2006) 177 final // http://ec.europa.eu.

26 См., например: Публичные услуги и право / под ред. Ю.А. Тихомирова. - М., 2007; Васильева А.Ф. Указ. соч.; Морозова Е.В. Публичные услуги: теоретико-правовой аспект: дис. ... канд. юрид. наук. - М., 2009; Величкина Е.А. Гражданско-правовое регулирование обязательств по оказанию публичных услуг: дис. ... канд. юрид. наук. - Волгоград, 2010; Алексеева Ю.А. Исследование эффективности и качества оказания государственных и муниципальных услуг (функций) в электронном виде: дис. ... канд. юрид. наук. Астрахань, 2011; Бесчастнова Л.В. Административно-правовое регулирование государственных услуг: дис. ... канд. юрид. наук. - Саратов, 2008. 
ственными и муниципальными органами, учреждениями и в случаях, предусмотренных законом, иными юридическими лицами. Кроме того, указанная норма раскрывает взаимосвязанное понятие государственного (муниципального) задания, под которым понимается документ, устанавливающий требования к составу, качеству и (или) объему (содержанию), условиям, порядку и результатам оказания государственных (муниципальных) услуг.

Начиная с 2008 г. в бюджетном законодательстве наряду с понятием государственных и муниципальных услуг используется также термин государственные $u$ муниципальные работьл. На законодательном уровне названные категории каким-либо образом не разграничиваются и употребляются, как правило, в качестве парных, однако некоторые подзаконные акты их дифференцируют, прежде всего, на этапе формирования государственного задания ${ }^{27}$. По-видимому, здесь сказалось влияние гражданско-правовой доктрины, которая традиционно разделяет работы, применительно к которым ценность имеет результат, и услуги, представляющие интерес с точки зрения самого процесса. С публично-правовых позиций это терминологическое различие не является принципиальным, в особенности в сравнении с европейской понятием публичных служб (услуг), которое является наиболее общим и отличается чрезвычайно широким содержанием. Потому представляется допустимым применять понятие услуг в качестве обобщающего.

Бюджетному законодательству в целом корреспондирует Указ Президента РФ от 9 марта 2004 г. № 314 «О системе и структуре федеральных органов исполнительной власти» ${ }^{28}$ (далее - Указ № 314), который трактует функцию по оказанию государственных услуг как предоставление федеральными органами исполнительной власти непосредственно или через подведомственные им федеральные государственные учреждения либо иные организации безвозмездно или по регулируемым органами государственной власти ценам услуг гражданам и организациям в области образования, здравоохранения, социальной защиты населения и в других областях, установленных федеральными законами (подп. «д» п. 2).

Однако в рамках проводимой административной реформы категория государственных и муниципаль-

27 См., напр.: Положение о формировании государственного задания в отношении федеральных бюджетных и казенных учреждений и финансовом обеспечении выполнения государственного задания, утв. Постановлением Правительства РФ от 2 сентября 2010 г. № 671 // СЗ РФ. - 2010. - № 37. Ст. 4686.

28 СЗ РФ. - 2004. - СТ. 945. ных услуг стала включать не только и не столько услуги социальной направленности, но прежде всего действия и решения административно-правового распорядительного характера ${ }^{29}$. Наконец, в 2010 г. был принят Федеральный закон от 27 июля 2010 г. № 210-Ф3 «Об организации предоставления государственных и муниципальных услуг» ${ }^{30}$ (далее - Закон № 210-Ф3), который определил данные услуги как деятельность органов публичной администрации, которая направлена на реализацию возложенных на нее функций и осуществляется по запросам заявителей (ст. 2).

Несмотря на прогрессивные изменения в действующем законодательстве, систему регулирования сферы публичных услуг нельзя признать сформированной в законченном виде по целому ряду причин. Более того, сам термин «публичные услуги» так и не получил нормативного закрепления.

2.1. Закон № 210-Ф3 и принимаемые в его исполнение административные регламенты сориентированы главным образом на регулирование услуг, предоставляемых государственными и муниципальными органами. Такие услуги можно обозначить в качестве админиcтративных , по сути они носят навязанный характер и основаны на использовании эксклюзивных суверенных полномочий вне конкурентной среды (выдача лицензии, разрешения, государственная регистрация и т.п.).

Услуги, оказываемые государственными и муниципальными учреждениями и другими организациями, в которых размещается государственное или муниципальное задание (заказ), не названы в Законе № 210Ф3 в качестве государственных и муниципальных и по сути позиционируются в качестве самостоятельной разновидности услуг вразрез с терминологией, закрепленной в БК РФ. При этом Закон распространяется на ту их незначительную часть, которая предоставляется в электронной форме и включена в специальный перечень, утвержденный Правительством России (как правило, речь идет о действиях технического или административного характера по предоставлению информации, приему заявок и иных документов, выдаче направлений и т.п.) $)^{31}$. Подавляющая часть услуг, ока-

29 См.: Концепция административной реформы в Российской Федерации в 2006-2008 годах, утв. Распоряжением Правительства РФ от 25 октября 2005 г. № 1789-р // СЗ РФ. 2005. - № 46. - Ст. 4720; Концепция снижения административных барьеров и повышения доступности государственных и муниципальных услуг на 2011-2013 гг., утв. Распоряжение Правительства РФ от 10 июня 2011 г № 1021-p // СЗ РФ. 2011. - № 26. - Ст. 3826.

30 С3 РФ. - 2010. - № 31. - Ст. 4179.

31 См. Распоряжение Правительства РФ от 25 апреля 2011 г. № 729-p // СЗ РФ. - 2011. - № 18. - Ст. 2679. 
зываемых учреждениями и иными организациями на основе государственного или муниципального задания либо заказа, не способна предоставляться в электронной форме, поскольку носит социальный характер и строится на непосредственном взаимодействии с потребителями услуг в рамках длящихся отношений, причем, как правило, с использованием специально приспособленных имущественных комплексов (медицинские обслуживание, образование и т.д.). Подобные услуги не составляют эксклюзивные функции публичной администрации, однако государство и муниципалитеты в рамках решения социальных задач обеспечивают и полностью или частично финансируют их предоставление силами подведомственных учреждений и иных привлеченных организаций.

Описанная рассогласованность подходов к определению государственных и муниципальных услуг в БК РФ и Законе № 210-Ф3, а также отсутствие легальной дифференциации услуг, на наш взгляд, выступают наиболее существенными недостатками существующей системы нормативного регулирования ${ }^{32}$.

2.2. Закон № 210-ФЗ ввел категорию услуг, которые являются необходимыми и обязательными для предоставления государственных и муниципальных услуг (ст. 9). Такие сопутствуюшие услуги, по сути, не носят самостоятельного характера, а являются элементом предоставления административных услуг (к примеру, для выдачи разрешения на строительство необходима экспертиза проектной документации). Отметим, что Закон не ограничивает перечень субъектов, которые вправе и обязаны оказывать сопутствующие услуги, и Верховный Суд РФ пришел к выводу, что в их число могут входить не только государственные и муниципальные учреждения и предприятия, но и частные лица, признав недействующими ограничительные правила, ранее установленные Правительством России ${ }^{33}$.

Выделение в законе рассматриваемой категории услуг еще больше запутывает ситуацию. С одной стороны, сопутствующие услуги могут предоставляться государственными или муниципальными учреждениями во исполнение соответствующего задания, а следовательно, будут признаваться самостоятельными государственными или муниципальными услугами с точки зрения БК РФ. С другой стороны, если такие ус-

\footnotetext{
32 Добавим к этому, что отдельные законодательные акты демонстрируют комбинированный подход в попытке объединить административные и социальные государственные услуги в определенной сфере (см., например: Закон РФ от 19 апреля 1991 г. № 1032-1 «О занятости населения в Российской Федерации» // С3 РФ. - № 17. - Ст. 1915.

33 См.: Решение Верховного Суда РФ от 28 декабря 2010 г. № ГКПИ10-1298 // СПС «КонсультантПлюс».
}

луги оказываются частными лицами (например, организациями, осуществляющими кадастровые работы), соответствующая деятельность выходит за пределы государственных и муниципальных услуг с позиций не только Закона № 210-Ф3, но и БК РФ, однако сохраняет черты публично значимых услуг, частично регулируемых Законом № 210-Ф3, административными регламентами, а также специальными нормативными актами.

По своей природе предоставление сопутствующих услуг в подавляющем большинстве случаев представляет собой деятельность, связанную с извлечением дохода (оказание данных услуг на безвозмездной основе - скорее редкость). При этом субъекты, предоставляющие возмездные сопутствующие услуги зачастую занимают монопольное положение на рын$\mathrm{\kappa e}^{34}$, в связи чем закон устанавливает по отношению к ним правила регулируемого ценообразования. Однако в действительности порядок определения платы за оказание рассматриваемых услуг предусмотрен лишь применительно к подведомственным публичной администрации государственным и муниципальным организациям, и он не распространяется на частные независимые организации ${ }^{35}$.

2.3. За рамками БК РФ и Закона №210-ФЗ остались услуги, оказываемые населению бесплатно в рамках обязательного социального, в том числе медицинского, страхования. Предоставление таких услуг не охватывается государственными и муниципальными заданиями и не обеспечивается бюджетными ассигнованиями, так как в их основе лежит не плановый показатель, а тот или иной жизненный риск. Поэтому основанием для оказания соответствующих услуг выступает не задание органа публичной администрации, а обязательство перед страховщиком в рамках той или иной программы социального страхования (к примеру, обязанность учреждения здравоохранения бесплатно оказать медицинскую помощь застрахованному лицу в рамках системы обязательного медицинского страхования). На наш взгляд, нет веских оснований для исключения подобной деятельности из сферы публичных услуг, тем более что она вполне укладывается в трактовку государственных услуг, заложенную в Указе № 314. Высказанная точка

34 См.: п. 6 разд. IV Концепция снижения административных барьеров и повышения доступности государственных и муниципальных услуг на 2011-2013 годы.

35 См., напр.: Правила определения размера платы за оказание услуг, которые являются необходимыми и обязательными для предоставления федеральными органами исполнительной власти государственных услуг, утв. Постановлением Правительства РФ от 6 мая 2011 г. № 352 // СЗ РФ. - 2011. № 20. - Ст. 2829. 
зрения в полной мере подкрепляется рассмотренным выше европейским опытом.

При этом оказание подобных услуг, как правило, имеет черты экономической деятельности, поскольку ее осуществление базируется на получении оплаты за счет средств фондов обязательного страхования. Причем в последние годы в данную сферу все больше проникают конкурентные начала, что наиболее явно прослеживается в области здравоохранения: 1) в системе обязательного медицинского страхования, способны участвовать медицинские организации любой организационно-правовой формы, а также индивидуальные предприниматели; 2) граждане как застрахованные лица имеют право выбора медицинской организации из числа участвующих в системе обязательного страхования; 3) медицинские организации, выбранные застрахованными и оказавшие им медицинскую помощь, получают оплату в соответствии с установленными тарифами за счет средств, аккумулируемых в фондах обязательного медицинского страхования ${ }^{36}$.

2.4. Вовсе за пределами Закона № 210-ФЗ и БК РФ остались публично значимые услуги, оказываемые государственными и муниципальными учреждениями сверх государственных и муниципальных заданий и программ обязательного социального страхования. При этом подобные услуги могут укладываться в категорию государственных в их трактовке, зафиксированной в Указе № 314, который не упоминает такой инструмент, как государственное задание, а делает акцент на условиях предоставления (безвозмездно или по регулируемым ценам) и организаторе их предоставления - государственный орган, который самостоятельно оказывает услугу или поручает осуществление соответствующей деятельности специально созданной или привлеченной организации. По своему характеру анализируемая деятельность в большинстве случаев носит обязательный характер, осуществляется по особым правилам и по сути незначительно отличается от аналогичных услуг, оказываемых в пределах доведенного задания (например, платное обучение в государственных вузах). Не способен служить четким критерием разграничения рассматриваемых групп услуг и признак их возмездности для потребителей, поскольку государственные и муниципальные услуги, осуществляемые во исполнение задания, могут предусматривать взимание платы (п. 1 ст. 69.2 БК РФ).

На наш взгляд, было бы неверно трактовать эти услуги сугубо с гражданско-правовой точки зрения,

36 См.: ст. 15, 16, 20 и др. Федерального закона от 29 ноября 2010 г. № 326-Ф3 «Об обязательном медицинском страховании в Российской Федерации» // С3 РФ. - 2010. - № 49. - Ст. 6422. в частности в контексте обыкновенной приносящей доход деятельности учреждений. Подчеркнем, что публично значимый характер деятельности, обязательность ее осуществления (даже в отсутствие конкретных параметров, определяемых в задании), организация ее осуществления публичной администрацией, целевой характер используемого государственного и муниципального имущества, равный и гарантированный доступ к услугам со стороны потребителей - все эти существенные аспекты могут быть объяснимы лишь категориями публичного права с позиций осуществления государственных и муниципальных функций. С точки зрения гражданского законодательства специфику рассматриваемой деятельности адекватно определить невозможно, в частности установленная ст. 426 ГК РФ конструкция публичного договора здесь малопригодна, поскольку применима исключительно к коммерческим организациям.

2.5. В рамки формирующегося института публичных услуг не укладываются деятельность государственных и негосударственных коммерческих организаций, которая имеет особое публичное значение (энерго-, водо-, газоснабжение, услуги почты и связи, транспорт общего пользования и т. п.), а потому должна осуществляться в обязательном порядке в интересах общества по регулируемым правилам и стандартам. Исходя из этих соображений некоторые общезначимые виды экономической деятельности объявляются прерогативами государства, и правом на их осуществление наделяются отдельные подконтрольные ему хозяйствующие субъекты: эксплуатация единой системы газоснабжения, объектов инфраструктуры железнодорожного транспорта общего пользования, деятельность в области ядерного энергопромышленного комплекса и др. Однако в подавляющем большинстве случаев в сферы общезначимой экономической деятельности допускаются хозяйствующие субъекты, которые не подконтрольны государству или муниципалитетам.

В целом публичные образования, будучи ответственными за гарантированное осуществление соответствующих функций, должны организовать их выполнение одним из следующих способов: (1) создать, подведомственные организации, наделить их необходимым имуществом, обеспечить их эффективное функционирование; (2) уполномочить частные лица, передав им необходимое публичное имущество (концессия); (3) разрешить деятельность частных лиц без передачи им публичного имущества, обеспечив при этом действенный контроль за соблюдением общественных интересов. Однако во всех случаях деятельность хозяйствующих субъектов отвечает признакам публичных услуг. 
Показательно в связи с этим, что КС РФ в одном из своих недавних Постановлений пришел к выводу, что теплоснабжение как публичная услуга, связанная с удовлетворением основных, жизненно важных потребностей человека, обеспечивается в России как социальном государстве в том числе при участии местного самоуправления как публичной власти, наиболее приближенной к населению ${ }^{37}$. Схожим образом Суд квалифицировал услуги по перевозке пассажиров воздушным транспортом в качестве социально необходимой и публичной значимой деятельности (публично значимых услуг), которая воплощает в себе публичный интерес ${ }^{38}$. В литературе также появляется трактовка отдельных видов деятельности общеэкономического значения в качестве публичных услуг ${ }^{39}$. Эта идея вполне понятна и соответствует европейскому опыту, где подобные направления публично значимой деятельности трактуются как экономические службы общего значения (SGEI).

В условиях действующего российского законодательства с позиций института публичных услуг общеэкономического значения могут быть рассмотрены следующие пересекающиеся категории: 1) так называемые регулируемые виды деятельности: теплоснабжение, водоснабжение и водоотведение, электроснабжение, газоснабжение, транспорт общего пользования и т.п.; 2) универсальные услуги в области связи, в частности почтовой, и др. сферах ${ }^{40}$; 3) деятельность субъектов естественных монополий. Оказание подобных услуг строиться на основе следующих принципов: обязательности обслуживания неопределенного круга лиц, гарантированности и непрерывности, недискриминации, доступности цены, соблюдения установленных требований качества и стандартов обслуживания, обременения имущества хозяйствующего субъекта установленным целевым назначением и др.

Все рассмотренные выше разновидности услуг, несмотря на их разнородность, имеют решающее сходство - они представляют собой деятельность, которая осуществляется во всеобщем интересе, направлена на удовлетворение публично значимых потребностей

37 Постановление КС РФ от 29 марта 2011 г. № 2-П // СЗ РФ.2011. - № 15. - Ст. 2190.

38 ПостановлениеКСРФот20декабря2011 г.№29-П//СЗРФ.2012. - № 2. - Ст. 397.

39 См., например: Макеева Е.М. Оказание публичных услуг в энергетической отрасли (на примере России и европейских стран) // Административное право и процесс. - 2010. - № 5.

40 Отметим, что понятие универсальных услуг заимствовано из зарубежного законодательства (прежде всего ЕС), где оно уже длительное время используется применительно к сфере телекоммуникаций. частных лиц и должна быть обеспечена (гарантирована) государством. Таким образом, на сегодня сложились объективные предпосылки для утверждения в российской правовой системе института публичных услуг (служб общего значения) именно в том понимании, которые является общепринятым в странах континентального права и прежде всего ЕС.

Правовой режим публичных услуг требует дифференциации, однако закрепленные в действующем законодательстве категории государственных и муниципальных услуг, даже с учетом их различной трактовки, не отражают всего спектра публичных услуг. В связи с этим может быть предложена более обширная их классификация: (1) по критерию эксклюзивности предоставления: составляющие прерогативы государства, муниципальных образований и не относящиеся к таковым; (2) в зависимости от заинтересованности потребителей: навязанные и гарантированные; (3) по содержанию: административные, социальные, по обеспечению жизненно важными ресурсами, транспортные и т.д.; (4) по критерию платности: безвозмездные, облагаемые сбором, оплачиваемые по регулируемым и нерегулируемым ценам и т.д.; (5) в зависимости от уровня публичной власти, в функции которой входит обеспечение предоставления услуг: публичные услуги федерального, регионального и муниципального значения.

Однако в качестве базового разграничения публичных услуг целесообразно принять их деление на экономические и неэкономические, которое в результате длительных дискуссий сложилось в ЕС: публичные услуги экономического характера предоставляются за плату в пользу поставщика услуг, в то время как услуги неэкономического характера оказываются без взимания им оплаты. Подобная дифференциация публичных услуг имеет ключевое значение, по следующим причинам:

- экономический характер услуги требует использования юридической конструкции возмездного договора, поскольку оплата в пользу поставщика услуги в данной ситуации не может быть квалифицирована в качестве фискального взимания. При этом в большинстве случаев, по нашему мнению, речь идет о конструкции частноправового договора, однако в той или иной степени видоизмененной и приспособленной для публичных целей законодательными актами специального действия (смешанный договор);

- на оказание публичных услуг экономического характера способны распространяться гарантии свободы осуществления соответствующей деятельности и допустимости ее ограничения лишь в конституционно одобряемых целях;

- экономический характер публичных услуг вовлекает их в сферу действия законодательства о защите кон- 
куренции, которое предполагает, в частности, отделение функций хозяйствующих субъектов от функций органов власти, развитие соперничества между субъектами оказания публичных услуг, недопустимость необоснованных государственных и муниципальных преференций отдельным хозяйствующим субъектам, а также ограничений конкуренции между ними и т.п. Данное обстоятельство приобретает особое значение с учетом международных обязательств России по обеспечению свободы торговли услугами в рамках Единого экономического пространства и ВТО.

С этих позиций необходимо заключить, что публичные услуги экономического характера предоставляются хозяйствующими субъектами в условиях конкурентной среды и охватывают общезначимые услуги, которые: (1) оказываются по договору с потребителем и оплачиваются им по регулируемым или нерегулируемым ценам, при этом могут частично субсидироваться из бюджета; (2) оказываются в пользу потребителя, но оплачиваются на основании заключенного государственного (муниципального) контракта либо из фондов обязательного страхования. Регулирование подобных услуг отнюдь не исчерпывается гражданским законодательством, которое само по себе не способно обеспечить интересы общего блага, а строится на сбалансированном взаимодействии частных и публичных начал.
Для характеристики правового режима рассматриваемых услуг в европейской науке предложения концепция трехсторонних отношений: потребитель услуги - поставщик услуги - регулирующий орган ${ }^{41}$.

Публичные услуги неэкономического характера охватывают главным образом: (1) административные услуги, представляемые государственными и муниципальными органами, а также некоторыми учреждениями в рамках Закона № 210-ФЗ без взимания оплаты либо при условии уплаты госпошлины; (2) социальные услуги, оказываемые государственными и муниципальными учреждениями на основе задания за счет финансового обеспечения из бюджета. Такие услуги всецело регулируются публичным (прежде всего административным) правом, конструкция договора между потребителем услуг и их поставщиком не применяется, а деятельность поставщика услуг не направлена на извлечение дохода. Делегирование функций по предоставлению административных услуг частному сектору (например, с использованием инструментов государственного или муниципального заказа) и придание им таким образом признаков экономической деятельности вряд ли допустимо на современном этапе развития общественных отношений в России. Однако, в сфере социальных услуг такая тенденция, напротив, отражает одно из направлений реформы государственного управления.

\section{Библиографический список:}

1. Auby J.-M., Bon P., Auby J.-B. Droit administratif des biens. 4e éd. P.: — Dalloz, 2003.

2. Corradino M. Il diritto amministrativo. II edizione. Padova: CEDAM, 2009.

3. Dupuis G., Guédon M.-J., Chrétien P. Droit administratif. 9e éd. P.: — Dalloz, 2004.

4. El Derecho Administrativo Iberoamericano (Estudios y Comentarios, № 9) / Dir. S. González-Varas Ibáñez, Coord. F. Villalba Pérez. Granada (España): Instituto Nacional de Administración Pública, Unión Iberoamericana de Municipalistas, 2005.

5. Forsthoff E. Rechtsfragen der leistenden Verwaltung. — Stuttgart: Kohlhammer. 1959.

6. Gaudemet Y. Traité de droit administratif. T. 1. Droit administratif general. 16e éd. P.: LGDJ, 2001.

7. Market Integration and Public Services in the European Union / Ed. by M. Cremona. — New York: Oxford University Press, 2011.

8. Papier H.-J. Recht der öffentlichen Sachen. 3. Aufl. — Berlin: De Gruyter, 1998.

9. Rivero J., Waline J. Droit administrative. 19e éd. P.: — Dalloz, 2002.

10. Sánchez Morón M. Derecho administrativo: Parte general. $7^{\mathrm{a}}$ ed. — Madrid: Tecnos, 2011.

11. Social Services of General Interest in the EU / Ed. U.U. Neergaard, E. Szyszczak, J.W. van de Gronden, M. Krëajewski. Springer, 2013.

12. The Changing Legal Framework for Services of General Interest in Europe. Between Competition and Solidarity / Ed. by M. Krajewski, U. Neergaard, J. van de Gronden. The Hague: T.M.C. Asser press. 2009.

13. Административные процедуры и контроль в свете европейского опыта / под ред. Т. Я. Хабриевой, Ж. Марку. M., 2011.

14. Алексеева Ю.А. Исследование эффективности и качества оказания государственных и муниципальных услуг (функций) в электронном виде: дис. ... канд. юрид. наук. Астрахань, 2011.

$41 \quad$ Micklitz H.-W. Op. cit. - P. 76-79, 88-89. 
15. Бесчастнова Л.В. Административно-правовое регулирование государственных услуг: дис. ... канд. юрид. наук. - Саратов, 2008.

16. Васильева А. Ф. Административно-правовое регулирование публичных услуг в Германии и России: сравнительно-правовой анализ: дис. ... канд. юрид. наук. - СПб., 2009.

17. Величкина Е.А. Гражданско-правовое регулирование обязательств по оказанию публичных услуг: дис. ... канд. юрид. наук. - Волгоград, 2010.

18. Европейский Союз: Основополагающие акты в редакции Лиссабонского договора с комментариями / отв. ред. С.Ю. Кашкин, пер. А.О. Четвериков. - М., 2007.

19. Макеева Е.М. Оказание публичных услуг в энергетической отрасли (на примере России и европейских стран) // Административное право и процесс. 2010. № 5.

20. Морозова Е.В. Публичные услуги: теоретико-правовой аспект: дис. ... канд. юрид. наук. — М., 2009.

21. Публичные услуги и право / под ред. Ю.А. Тихомирова. - М., 2007.

22. Талапина Э.В. Административное право Франции сегодня // Ежегодник сравнительного правоведения. - M., 2004.

\section{References (transliteration):}

1. Auby J.-M., Bon P., Auby J.-B. Droit administratif des biens. 4e éd. P.: Dalloz, 2003.

2. Corradino M. Il diritto amministrativo. II edizione. Padova: CEDAM, 2009.

3. Dupuis G., Guédon M.-J., Chrétien P. Droit administratif. 9e éd. P.: Dalloz, 2004.

4. El Derecho Administrativo Iberoamericano (Estudios y Comentarios, № 9) / Dir. S. Gonzélez-Varas Ibééez, Coord. F. Villalba Pérez. Granada (Espaéa): Instituto Nacional de Administracién Péblica, Unié243;n Iberoamericana de Municipalistas, 2005.

5. Forsthoff E. Rechtsfragen der leistenden Verwaltung. Stuttgart: Kohlhammer. 1959.

6. Gaudemet Y. Traité de droit administratif. T. 1. Droit administratif general. 16e éd. P.: LGDJ, 2001.

7. Market Integration and Public Services in the European Union / Ed. by M. Cremona. New York: Oxford University Press, 2011.

8. Papier H.-J. Recht der éffentlichen Sachen. 3. Aufl. Berlin: De Gruyter, 1998.

9. Rivero J. , Waline J. Droit administrative. 19e éd. P.: Dalloz, 2002.

10. é225;nchez Morén M. Derecho administrativo: Parte general. ed. Madrid: Tecnos, 2011.

11. Social Services of General Interest in the EU / Ed. U.U. Neergaard, E. Szyszczak, J.W. van de Gronden, M. Kreajewski. Springer, 2013.

12. The Changing Legal Framework for Services of General Interest in Europe. Between Competition and Solidarity / Ed. by M. Krajewski, U. Neergaard, J. van de Gronden. The Hague: T.M.C. Asser press. 2009.

13. Administrativnye protsedury i kontrol' v svete evropeyskogo opyta / Pod red. T. Ya. Khabrievoy, Zh. Marku. M., 2011.

14. Alekseeva Yu.A. Issledovanie effektivnosti i kachestva okazaniya gosudarstvennykh i munitsipal'nykh uslug (funktsiy) v elektronnom vide: Dis. ... kand. yurid. nauk. Astrakhan', 2011.

15. Beschastnova L.V. Administrativno-pravovoe regulirovanie gosudarstvennykh uslug: Dis. ... kand. yurid. nauk. Saratov, 2008.

16. Vasil'eva A. F. Administrativno-pravovoe regulirovanie publichnykh uslug v Germanii i Rossii: sravnitel'nopravovoy analiz: Dis. ... kand. yurid. nauk. SPb., 2009.

17. Velichkina E.A. Grazhdansko-pravovoe regulirovanie obyazatel'stv po okazaniyu publichnykh uslug: Dis. ... kand. yurid. nauk. Volgograd, 2010.

18. Evropeyskiy Soyuz: Osnovopolagayushchie akty v redaktsii Lissabonskogo dogovora s kommentariyami / Otv. red. S.Yu. Kashkin, per. A.O. Chetverikov. M., 2007.

19. Makeeva E.M. Okazanie publichnykh uslug v energeticheskoy otrasli (na primere Rossii i evropeyskikh stran) // Administrativnoe pravo i protsess. 2010. № 5.

20. Morozova E.V. Publichnye uslugi: teoretiko-pravovoy aspekt: Dis. ... kand. yurid. nauk. M., 2009.

21. Publichnye uslugi i pravo / Pod red. Yu.A. Tikhomirova. M., 2007.

22. Talapina E.V. Administrativnoe pravo Frantsii segodnya // Ezhegodnik sravnitel'nogo pravovedeniya. M., 2004. 